\title{
Pelatihan Mengenali Emosi Marah Bagi Siswa SMP
}

\section{Training in Recognizing Angry Emotions for Junior High School Students}



\begin{abstract}
Abstrak
Sebagai makhluk sosial manusia selalu berinteraksi antara satu dengan yang lainnya, inilah yang selalu dilakukan oleh setiap individu. Dalam berinteraksi emosi selalu muncul dalam dri seseorang, kemudian memunculkan sebuah sikap dan pikiran untuk bertindak sesuai dengan keadaan dirinya. Kemampuan bertindak itu kemudian memunculkan sebuah ekspresi emosional Salah satunya adalah ekpresi emosi marah, inilah yang menjadi salah satu masalah yang timbul pada diri setiap remaja (siswa). Pelatihan ini mengambil lokasi di SMP Muhammadiyah Palangkaraya dengan alasan hasil observasi dan wawancara dari guru kelas dan konselor sekolah, berdasarkan hasil angket mengenai pengetahuan tentang emosi marah padaa pretest dalam kategori rendah dan belum pernah dilakukan pelatihan yang serupa di sekolah tersebut. Hasil dari kegiatan pelatihan ini menunjukan bahwa ada peningkatan nilai rerata pemahaman siswa dalam mengenali emosi marah. Nilai rerata pretest 91,8 (kategori sedang) dan rerata posttest 127,28 (kategori tinggi).
\end{abstract}

\begin{abstract}
As social beings, humans always interact with each other, this is what is always done by every individual. In interacting emotions always appear in someone's, then bring up an attitude and mind to act according to his circumstances. The ability to act then raises an emotional expression. One of them is the expression of angry emotions, this is one of the problems that arise in every teenager (student). This training took place in MuhammadiyahYunior High School Palangkaraya on the grounds of the results of observations and interviews from class teachers and school counselors, based on the results of a questionnaire about the knowledge of angry emotions in pretest is in a low category, no similar training had been conducted at school. The results of this training activity show that there is an increase in the average value of students' understanding of recognizing angry emotions. This means the pretest score is 91.8 (medium category) and the posttest average is 127.28 (high category).
\end{abstract} (http://creativecommons.org/licenses/by-sa/4.0/). DOI: https://doi.org/10.33084/pengabdianmu.v6i1.1433

\section{PENDAHULUAN}

Perkembangan zaman saat ini telah menjadikan perilaku manusia yang sangat kompleks. Hal ini dipengaruhi oleh berbagai faktor baik ekternal maupun internal. Faktor ekternal adalah faktor yang mempengaruhi perilaku yang berasal dari luar diri seseorang, seperti; agama, pendidikan, kebudayaan, dan social ekonomi, dan faktor internal adalah faktor yang mempengaruhi perilaku yang berasal dari dalam diri seseorang, seperti: jenis kelamin, sifat fisik, keturunan, bakat dan minat, dan intelegensi (Wardhani, 2006).

Faktor-faktor yang mempengaruhi perilaku tersebut di atas, akan berdampak pada timbulnya emosi seseorang yang berakibat dapat memunculkan perilaku baru. Emosi merupakan sebuah respon atau reaksi yang cepat atas menanggapi stimulus baik secara internal maupun eksternal. Secara internal yang terjadi dalam diri seperti apa yang dipikirkan dan apa yang dirasakan yang dapat menimbulkan emosi. Secara eksternal yang terjadi diluar 
diri seperti dari orang lain (tindakan dan tanggapannya), pengaruh biologis dan lingkungan, hal ini juga dapat menimbulkan emosi (Atmoko, 2011).

Emosi adalah sebuah reaksi tubuh sebagai respon terhadap situasi atau peristiwa yang terjadi dalam lingkungan. Emosi merupakan keadaan yang ditimbulkan oleh suatu rangsangan atau situasi tertentu yang menyebabkan terjadinya perubahan perilaku pada diri remaja (Fatchurahman \& Pratikto, 2012). Dari emosi itulah pada dasarnya disebut sebagai temperamen. Temperamen adalah cara biologis untuk mendekati dan bereaksi terhadap situasi obyek tertentu yang akhirnya dapat menyebabkan terjadinya perubahan perilaku pada diri seseorang, yang akhirnya dapat disebut sebagai karakteristik seseorang (Nurhayani, 2014).

Pengubahan tingkah laku berpengaruh besar pada tatanan kehidupan sosial seseorang seiring dengan perkembangan zaman yang begitu kompleks saat ini. Karena itu, emosi dilibatkan di berbagai aspek kehidupan remaja, mulai dari fluktuasi hormonal dari masa pubertas hingga kesendirian dari depresi remaja. Disisi lain emosi itu sendiri terdapat berbagai jenis, di antaranya adalah emosi senang, sedih, marah, takut. Sementara itu hasil tes kecemasan (Rowe \& Fitness, 2018), emosi itu sendiri terdapat emosi negatif berdasarkan dari pada spektrum emosi yang lebih luas seperti kesedihan, kebosanan dan kemarahan (Al Baqi, 2015).

Kemarahan adalah emosi yang bersifat alami yang selalu dialami oleh setiap orang dari waktu ke waktu akan selalu muncul, meskipun hal ini kehadirannya terkadang tidak diinginkan. Sumber utama kemarahan menurut Averill (Sarwono, 2012) adalah hal-hal yang menganggu aktivitas untuk sampai pada tujuannya. Dengan demikian, ketegangan (stress) yang terjadi dalam aktivitas itu tidak mereda, bahkan bertambah. Untuk menyalurkan ketegangan-ketegangan itu individu yang bersangkutan menjadi marah (Fitrianah, 2018).

Emosi marah bila ditinjau dari perilaku seseorang, maka akan mempengaruhi kehidupan seseorang, terutama dalam hubungan soial atau interaksi soial seseorang. Dari berbagai interaksi sosial yang dilakukan seorang individu itu tentu akan memunculkan emosi dalam diri setiap individu. Dari emosi tersebut kemudian individu dapat menentukan sikap dan pikiran sehingga mampu bertindak sesuai dengan dirinya (Lewis \& HavilandJones, 2000).

Penjelasan diatas, memberikan pandangan bahwa setiap perilaku yang dilakukan oleh seseorang tidak terlepas ada sebuah emosi, apalagi dengan adanya emosi negatif dengan perilaku yang negatif pula. Dari emosi negatif inilah yang dapat membuat seseorang kehilangan akal sehatnya sehingga tidak mampu berfikir secara rasional lagi, ucapan dan perilakunya juga tidak dapat dikonrol (Diana, 2015). Perilaku remaja (siswa) pada saat ini sangatlah memprihatinkan dengan adanya perkelahian, perampokan, pencurian dan tidak jarang akibat dari adanya olok-olokan diantara sesama siswa, pertengkaran antar kelas, menendang dan memukul meja bahkan papan tulisnya dan lain-lain. Siswa yang demikian akhirnya tidak mampu lagi menguasai dirinya (Basri, 2015).

Berbagai fenomena di atas, maka sangatlah penting dilakukan sosialisasi berupa pemberian pemahaman kepada para siswa yang saat ini dalam proses kearah remaja (masa peralihan) dengan tugas-tugas perkembangan berat yang harus mereka lalui, tentang "Mengenal Emosi" dan Emosi Marah".pada SMP Muhammadiyah Palangkaraya. Materi ini diberikan sebagai salah satu bentuk layanan pribadi sosial. Layanan pribadi sosial ini sangat dibutuhkan siswa, karena itu layanan bimbingan pribadi sosial perlu diberikan kepada semua siswa SMP untuk membekali 
siswa dengan kemampuan berpikir logis/analitis; sistematis; kritis; dan kreatif serta kemampuan bekerja sama dalam proses pembentukan karakter kebajikan (Hambali, 2019).

Kegiatan pengabdian pada masyarakat ini dilaksanakan dengan tujuan untuk memberikan pemahaman mengenali emosi marah kepada siswa yang terindikasi perilaku emosional bermasalah, dengan pola pelaksanaan layanan pribadi sosial yang diberikan kepada siswa SMP Muhammadiyah Palangkaraya ini melalui pelatihan mengenali emosi marah.

\section{METODOLOGI}

Berdasarkan permasalahan sebagaimana telah dijelaskan pada bagian pendahuluan bahwa siswa dihadapkan berbagai fenomena dalam proses perkembangannya yaitu adanya pertengkatan dan saling mengolok yang berujung adanya perkelahian antar remaja, mencuri, pergaulan bebas dn lain-lain, sehingga dapat berdampak negatif bagi diri maupun lingkungannya. Kegiatan pengabdian kepada masyarakat ini sebagai salah alternatif upaya pemecahan masalah tersebut, yaitu dengan mengadakan pelatihan "Mengenali Emosi Marah" pada siswa pada SMP Muhammadiyah Palangkaraya. Adapun yang dilakukan pada kegiatan pelatihan ini, adalah:

1. Melakukan pretest sebelum materi disampaikan.

2. Penyampaian materi pelatihan "Mengenali Emosi Marah".

3. Pemberian motivasi kepada para siswa untuk memahami permasalahan kenakalan remaja dan emosi dalam pergaulan kehidupan sehari-hari termasuk di sekolah maupun di kelas.

4. Melakukan latihan disertai diskusi mengenai berbagai permasalahan dan pemecahannya tentang kenakalan remaja dan emosi dalam pergaulan.
5. Melakukan posttest setelah selesai materi disampaikan

Metode yang diterapkan untuk mencapai tujuan dalam kegiatan pengabdian pada masyarakat ini adalah pemutaran video, ceramah, tanya jawab dan latihan (praktik) disertai diskusi tentang berbagai permasalahan dalam kaitannya dengan pemateri yang disampaikan

\section{HASIL DAN PEMBAHASAN}

Hasil dari pelaksanaan pengabdian ini, akan dijabarkan dibawah ini sesuai dengan langkah-langkah atau metode pelaksanaan kegiatan pengabdian yang dilakukan. Setiap akhir sesi dilakukan evaluasi untuk mengetahui kemajuan peserta pada setiap sesi. Kegiata ini dilaksanakan pada hari Kamis, 20 Februari 2020 dengan jumlah siswa sebanyak 25 orang siswa. Penentuan subyek kegiatan pengabdian ini berdasarkan hasil observasi, wawancara dan dokumentasi dari guru kelas dan guru BK (Konselor), dimana para siswa tersebut dianggap selalu berbuat onar atau keributan, bahkan dianggap nakal.

Sosialisasi ini dikemas dalam bentuk melakukan pretest sebelum materi disampaikan selama 30 menit, penyampaian materi pembelajaran "Mengenal Emosi Marah"; berupa: pemutaran video 15 menit dan pemaparan dan penjelasan materi selama 45 menit disertai pemberian motivasi, melakukan latihan (praktik) dan diskusi interaktif serta tanya jawab selama 30 menit, dan melakukan posttest setelah selesai materi disampaikan selama 30 menit. Adapun hasil pretest dan posttest tentang pemahaman siswa dalam "Mengenal Emosi Marah" dapat dilihat pada Tabel I.

Tabel I. Skor berdasarkan hasil pretest dan postest Pemahaman Siswa dalam Mengenali Emosi Marah

\begin{tabular}{clclcl}
\hline No & Subyek & $\begin{array}{c}\text { Skor } \\
\text { Pretest }\end{array}$ & Kategori & $\begin{array}{c}\text { Skor } \\
\text { Posttest }\end{array}$ & Kategori \\
\hline 1 & HA & 80 & Rendah & 118 & Sedang \\
2 & DS & 120 & Sedang & 127 & Tinggi \\
3 & ZP & 78 & Rendah & 115 & Sedang \\
4 & KO & 121 & Sedang & 122 & Tinggi \\
5 & RM & 85 & Rendah & 120 & Sedang \\
\hline
\end{tabular}




\begin{tabular}{clclcl}
\hline 6 & MF & 75 & Rendah & 127 & Tinggi \\
7 & MZ & 89 & Sedang & 115 & Sedang \\
8 & ZB & 80 & Rendah & 122 & Tinggi \\
9 & AN & 77 & Rendah & 110 & Sedang \\
10 & Mg & 123 & Tinggi & 130 & Tinggi \\
11 & MS & 76 & Rendah & 122 & Tinggi \\
12 & No & 115 & Sedang & 130 & Tinggi \\
13 & Ri & 74 & Rendah & 125 & Tinggi \\
14 & TG & 77 & Rendah & 120 & Sedang \\
15 & RZ & 75 & Rendah & 110 & Sedang \\
16 & KL & 122 & Tinggi & 130 & Tinggi \\
17 & SM & 80 & Rendah & 125 & Tinggi \\
18 & Sf & 110 & Sedang & 125 & Tinggi \\
19 & MU & 80 & Rendah & 120 & Sedang \\
20 & LM & 125 & Tinggi & 130 & Tinggi \\
21 & RZ & 100 & Sedang & 115 & Sedang \\
22 & DM & 105 & Sedang & 137 & Tinggi \\
23 & SD & 78 & Rendah & 130 & Tinggi \\
24 & RF & 80 & Rendah & 115 & Sedang \\
25 & MJ & 70 & Rendah & 120 & Sedang \\
\hline Jumlah/ & $2295 /$ & Sedang & $3060 /$ & Tinggi \\
Rata-rata & 91,8 & & 122,4 & \\
\hline
\end{tabular}

Dari Tabel I diatas, terdapat perubahan data maka tingkat perubahan dalam mengenali emosi marah pada subjek, secara keseluruhan pada saat pretest dan postest dapat dilihat pada Gambar 1 berikut:

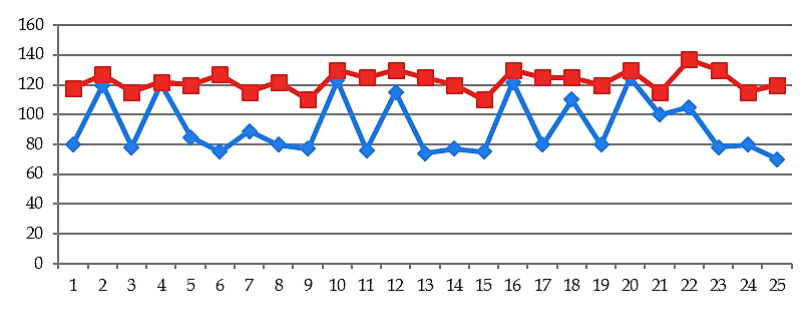
$\simeq$ Pre Test $\rightleftharpoons$ Post Test

Gambar 1. Hasil Pretest dan Postest disajikan dalam bentuk diagram batang

Tabel I menunjukkan bahwa hasil dari pretes yang diberikan kepada para siswa, menunjukkan bahwa dari 28 item pertanyaan diperoleh skor rata-rata 100,76 (kategori sedang) dengan skor minimal 70 dan skor maksimal 125. Berdasarkan kategori tingkat pemahaman siswa sebagaimana kriteria penilaian pada Tabel I, tingkat pemahaman siswa dalam mengenali emosi marah dapat dikategorikan kategori rendah dengan skor rata-rata 77,66 atau sebesar $60 \%$, kategori sedang dengan skor rata-rata 108,57 atau sebesar $28 \%$, dan kategori tinggi dengan skor rata-rata 123,3 atau sebesar $12 \%$. Terlihat bahwa dari hasil sebelum diberikan layanan kalisikal pada bidang bimbingan pribadi sosial terhadap sosialisasi dalam mengenali emosi marah, dikategorikan sebagian besar sedang.

Sedangkan dari hasil postes menunjukkan bahwa dari 28 item pertanyaan yang sama seperti yang telah diberikan pada pretes diperoleh bahwa nilai rata-rata pemahaman siswa terhadap materi mengenal emosi marah mengalami peningkatan dari hasil pretes, yakni dengan skor rata-rata 127,28 (kategori tinggi) dengan skor minimal naik menjadi 122 dan skor maksimal juga naik menjadi 137. Kategori pemahaman para siswa juga berubah yakni untuk pemahamannya pada kategori rendah sudah tidak ada atau $0 \%$, sedangkan kategori pemahaman sedang dari skor rata-rata 93,94 atau sebesar $68 \%$ meningkat menjadi skor rata-rata 116,18 atau sebesar $44 \%$ dan kategori tinggi yang semula skor ratarata 123,3 atau sebesar $12 \%$ menjadi skor rata-rata 127,28 atau sebesar 56\%. Hal ini menunjukkan bahwa materi tentang mengenali emosi marah yang diberikan kepada para siswa dengan metode ceramah, diskusi, tanya jawab dan pemutaran video dapat dipemahami oleh siswa dengan baik. Dokumentasi kegiatan disajikan pada Gambar 2 sampai 5 .

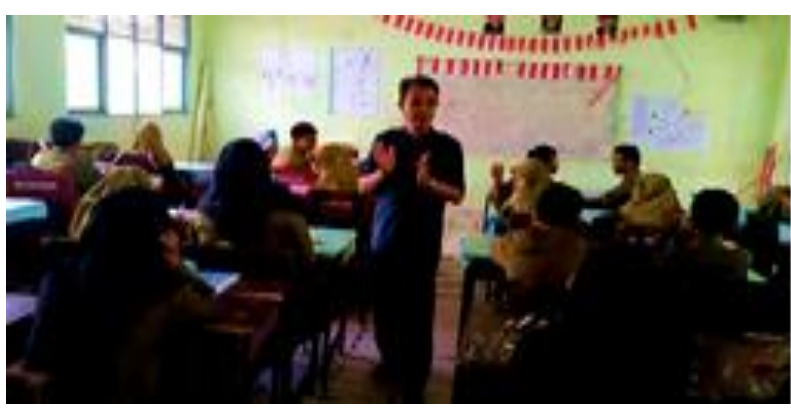

Gambar 2. Kegiatan pretest

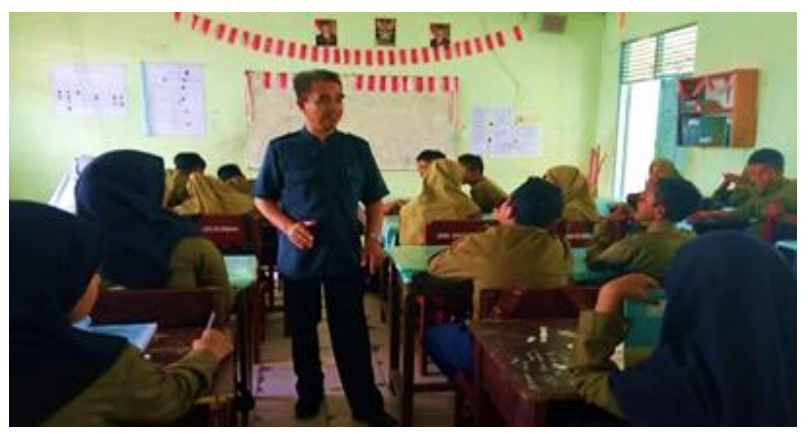

Gambar 3. Kegiatan posttest 


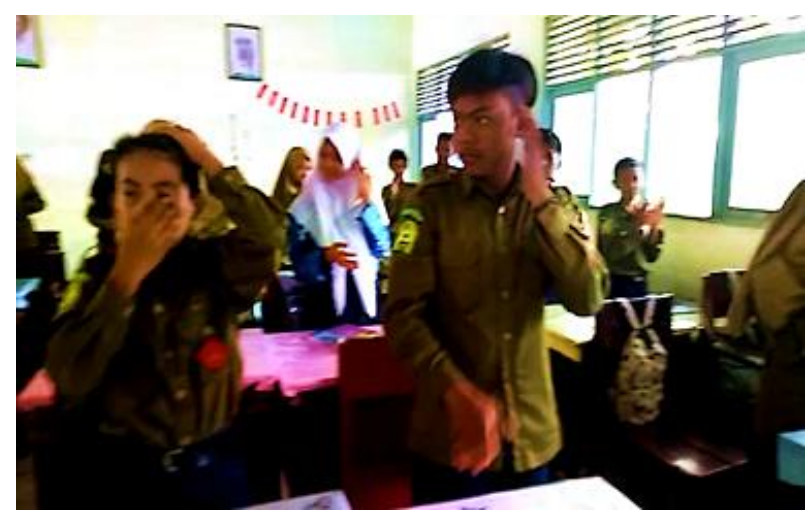

Gambar 4. Kegiatan pelatihan

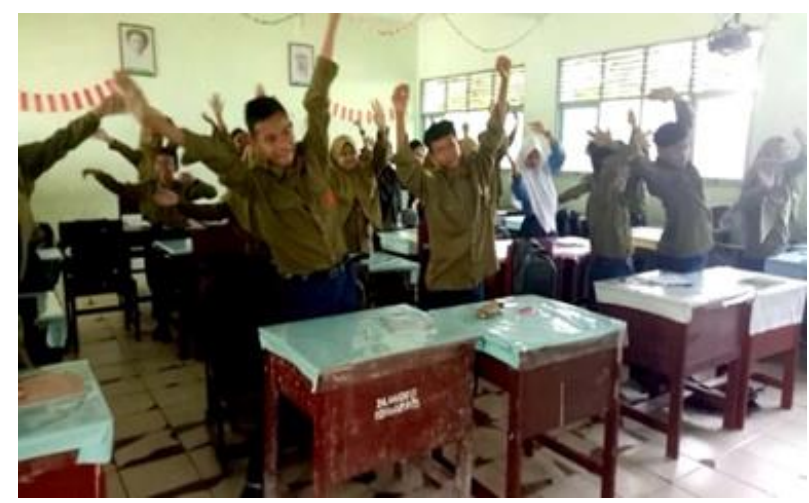

Gambar 5. Kegiatan pelatihan

Dalam usah mengenali emosi marah melalui layanan bimbingan pribadi sosial merupakan sebuah kebutuhan bagi diri siswa. Seiring dengan semakin kompleknya permasalahn yang dihadapi oleh para siswa maupun konselor di lingkungan masyarakat maupun di sekolah membuat konselor harus bekerja keras dalam memberikan berbagai jenis layanan bimbingan. Emosi adalah suatu reaksi terhadap diri seseorang atau kelompok orang. Emosi dapat ditunjukkan dengan cara ketika diri seseorang itu merasa senang terhadap sesuatu, marah kepada seseorang atau sekelompok orang, ataupun merasa takut terhadap sesuatu (Heydemans, 2009).

Dalam berbagai situasi dan kondisi berbeda-beda yang diiringin ekspresi tertentu emosi marah dapat muncul, ada yang bersifat positif dan negatif. Tiky Nindita menyebutkan sisi positif dari emosi marah yaitu membantu individu dalam mengatasi masalah dengan cara yang dapat diterima di lingkungan dalam berbagai macam situasi dan membantu meng-ekspreskan perasaan serta dapat membantu memotivasi diri sendiri dalam mencapai tujuan yang positif, sedangkan sisi negatif dari marah yaitu apabila marah diekspresikan dengan cara yang tidak pantas bertindak agresif baik verbal maupun fisik dapat mengganggu hubungan interpersonal (Utami, 2020).

Emosi-emosi tersebut penting karena sangat berpengaruh pada perilaku saat sekarang dan perilaku dimasa mendatang, terutama emosi negatif. Sedangkan marah sendiri merupakan reaksi terhadap sesuatu hambatan yang menyebabkan gagalnya suatu usaha atau perbuatan. Marah yang timbul seringkali diiringi oleh berbagai ekspresi perilaku (Al Baqi, 2015). Saat ini perilaku siswa tersebut apabila disimak sangatlah memprihatinkan.

Pengungkapan emosi marah menurut Safaria dan Saputra (2012) merupakan upaya mengkomunikasikan status perasaan ketika dalam kondisi marah dan bagaimana merespons emosi marah yang dirasakan. Respons dari adanya emosi marah ini dapat dilihat dari adanya perubahan raut wajah dan gerakan tubuh yang menyertai emosi, bagaiman cara mengungkapkan dan meyampaikan perasaannya kepada orang lain, sampai bagaimana menentukan perasaan orang lain. Pada saat itu seseorang individu itu tidak mempunyai saluran untuk mengungkapkan kemarahannya, sehingga ia akan mengungkapkannya melaui perasaan yang yang disebut "sakit".

Para siswa (remaja) tersebut perlu mengenali emosi marah; baik dari pengertian emosi, kemarahan, penyebab timbulnya emosi marah, ekpresi marah dan serta gejala-gejala yang timbul. Untuk mengenal gejalagejala tersebut sangatlah mudah. Sebagai contoh dalam kehidupan sehari-hari; seorang siswa yang tersenggol sedikit saja secara tidak sengaja sudah marah, diolokolok atau salah ucap sudah tersinggung, saling tatap 
muka. Ini menunjukkan bahwa para remaja (siswa) menujukkan bahwa cenderung sangat mudah marah walaupun sebenamya dipicu oleh hal yang sepele. Karena itu Safaria dan Saputra (2012) menyebutkan ekspresi kemarahan ini bagi siswa di sekolah dapat berupa reaksi emosional yang disebabkan adanya berbagai tekanan, agresivitas fisik dan kekecewaan, sehingga berakibat pada kemarahan, percekcokan verbal, perkelahian, tawuran hingga pembunuhaan dan pengrusakan fasilitas sekolah yang akhirnya berujung pada frustasi.

Lebih rinci lagi Seigman dan Snow menyebutkan terdapat tiga ekspresi marah yang mungkin muncul. (1) anger-out, yakni kemarahan yang muncul secara spontan dan cepat biasanya ditandai dengan teriakan, makian yang ditunjukkan kepada objek kemarahan. Obyek kemarahan ini diarahan kepada orang atau benda yang merupakan pengekspresian dari perasaan rasa benci, permusuhan/bermusuhan yang tertahan, rasa tersinggung, kekesalan, hilangnya kontrol diri dan berkata kasar. (2) anger-in, yakni kemarahan yang cenderung dirasakan sendiri tanpa mengungkapkannya dan biasanya disalurkan dengan imajinasi, (3) mood incongruent speech, yakni mengungkapkan kemarahan dengan suara pelan dan lembut. Pengekspresian ini terkait dengan level kemarahan yang dirasakan individu yakni mood incongruent speech muncul saat individu merasakan level kemarahan yang rendah, anger-in saat kemarahan level sedang, dan anger-out saat kemarahan yang dirasakan level tinggi (Al Baqi, 2015).

Safaria dan Saputra (2012) mengemukakan ciri ciri individu yang sedang marah: (a) ciri pada wajah, warna kulit berubah menjadi kuning pucat, tubuh terutama pada ujung-ujung jari bergetar keras, timbul buih pada sudut mulut, bola mata memerah, hidung kembang kempis, gerakan menjadi tidak terkendali, serta terjadi perubahan-perubahan lain pada fisik, (b) ciri pada lidah: meluncurnya makian, celaan, kata-kata yang menyakitkan, dan ucapan-ucapan keji yang membuat orang berakal sehat merasa risih untuk mendengarnya, (c) ciri pada anggota tubuh: munculnya keinginan untuk memukul, melukai, merobek, bahkan membunuh. Jika amarah tersebut tidak terlampiaskan pada orang yang dimarahinya, kekesalannya akan berbalik pada dirinya sendiri, (d) ciri pada hati: munculnya rasa benci, dendam dan dengki, menyembunyikan keburukan, merasa gembira dalam dukanya serta merasa sedih atas kegembiraannya, memutuskan hubungan, dan menjelek-jelekkannya.

Dari uraian sebagaiman dijelaskan di atas, untuk mengenali terhadap emosi merupakan suatu kemampuan seseorang untuk mengidentifikasi yang sesungguhnya dirasakan. Belajar mengenali emosi merupakan langkah dasar yang sangat penting. Terkadang emosi itu sulit untuk dikenali, mungkin pada saat merasa lelah, tidak bersemangat, hilang nafsu makan, dan tidak tahu bahwa kita sedang mengalami kesedihan. Pada saat jantung berdebar-debar, keringat dingin keluar, perut sakit, tidak tahu sedang merasakan cemas. Pada saat merasa tekanan darah naik, hilang kendali, dan nafas tidak teratur sehingga tidak menyadari bahwa dirinya sedang merasakan emosi marah (Fatchurahman, 2018).

Karena itu kemampuan mengenali emosi merupakan hal yang penting dan mendasar bagi setiap orang, sehingga mudah untuk menguasainya. Misalnya dengan melakukan pengamatan terhadap perilaku diri sendiri. Dengan demikian dapat mengetahui dan memahami situasi atau peristiwa yang menyebabkan munculnya reaksi dari emosi tersebut.

\section{KESIMPULAN}

Pelaksanaan dari pelatihan mengenali emosi marah ini menunjukan adanya peningkatan antara hasil pretest 
dan postest. Rerata pretest 100,76 (kategori sedang) dengan skor minimal 70 dan skor maksimal 125. Rerata posttest 127,28 (kategori tinggi) dengan skor minimal naik menjadi 122 dan skor maksimal juga naik menjadi 137. Pada saat pretes yang dilakukan kepada 25 orang siswa, berada pada kategori rendah dengan jumlah 15 orang dengan rerata 77,66 atau sebesar $60 \%$, ketagori sedang 7 orang dengan rerata 108,57 atau sebesar 28\%, dan tinggi 3 orang dengan rerata 123,3 atau sebesar $12 \%$. Sedangkan Hasil postest menunjukan peningkatan dalam mengenali emosi marah yaitu kategori rendah turun menjadi 0 orang atau $0 \%$, kategori sedang meningkat menjadi 11 orang siswa dengan rerata 116,18 atau sebesar $44 \%$ dan kategori tinggi meningkat menjadi 14 orang siswa dengan rerata 127,28 atau sebesar $56 \%$.

\section{UCAPAN TERIMA KASIH}

Terselenggaranya kegiatan pengab-dian ini berupa pelatihan mengenali emosi marah sampai artikel publish, penulis mengucapkan terima kasih kepada semua pihak yang telah membantu dalam kegiatan ini, terutapa kepada: (1) Ketua dan staf Lembaga Pengabdian Kepada Masyarakat Universitas Muhammadiyah Palangkaraya, (2) Kepala Sekolah, Wali kelas, guru BK besarta guru-guru pada SMP Muhammadiyah Palangkaraya, (3) Teman-teman dosen dan beberapa mahasiswa Program Studi Bimbingan dan Konseling FKIP UM Palangkaraya yang telah turut serta membantu pelaksanaan kegiatan ini.

\section{REFERENSI}

Al Baqi, S. 2015. Ekspresi Emosi Marah. Buletin Psikologi. 23(1):22-30. https:/ /doi.org/10.22146/bpsi.10574

Atmoko, A. 2011. Model Tindakan Guru Menanggapi Perilaku Siswa Dalam Pembelajaran. Jurnal Ilmu Pendidikan. 17(4):255-264. http://dx.doi.org/10.17977/jip.v17i4.2727
Basri, A.S.H. 2015. Fenomena Tawuran Antar Pelajar Dan Intervensinya. Hisbah: Jurnal Bimbingan Konseling dan Dakwah Islam. 12(1):1-25. https://doi.org/10.14421/hisbah.2015.121-06

Diana, R.R. 2015. Pengendalian Emosi Menurut Psikologi Islam. Unisia. 37(82):41-47.

Fatchurahman, M. 2018. Panduan Pelatihan Kesadaran Emosi Bagi Siswa SMTP. Malang: International Research and Development for Human Beings

Fatchurahman, M., Pratikto, H. 2012. Kepercayaan Diri, Kematangan Emosi, Pola Asuh Orang Tua Demokratis dan Kenakalan Remaja. Persona : Jurnal Psikologi Indonesia. 1(2):77-87. https://doi.org/10.30996/persona.v1i2.27

Fitrianah, R.D. 2018. Keseimbangan Emosi Dan Kesehatan Mental Manusia Dalam Persfektif Psikologi Agama. Jurnal Ilmiah Syi'ar. 18(1):91102.

http://dx.doi.org/10.29300/syr.v18i1.1285

Hambali, I.M. 2019. Analisis Kebutuhan Bimbingan Pribadi Sosial Berbasis Context, Experience, and Reality (CER) untuk Meningkatkan Karakter Kebajikan Siswa Sekolah Menengah Pertama. Jurnal Kajian Bimbingan dan Konseling. 4(1):37-45. http://dx.doi.org/10.17977/um001v4i12019p 037

Heydemans, E. 2009. Bimbingan Pribadi-Sosial : Emotional Awareness Bagi Remaja. Widya Warta : Jurnal Ilmiah Universitas Katolik Widya Mandala Madiun. 33(1):1-19.

Lewis, M., Haviland-Jones, J.M. 2000. Handbook of Emotion $2^{\text {nd }}$ Edition. New York: The Guilford Press

Nurhayani, N. 2014. Peran Figur Ayah Dan Ibu Dalam Membentuk Kemampuan Pengendalian Emosi Pada Anak. Jurnal Tarbiyah. 21(1):149174. http://dx.doi.org/10.30829/tar.v21i1.222

Rowe, A.D., Fitness, J. 2018. Understanding the Role of Negative Emotions in Adult Learning and Achievement: A Social Functional Perspective. Behavioral Sciences. 8(2):27. https:/ /dx.doi.org/10.3390/bs8020027

Safaria, T., Saputra, N.E. 2012. Manajemen Emosi: Sebuah Panduan Cerdas Bagaimana Mengelola Emosi PositifDalam Hidup Anda. Jakarta: Bumi Aksara 
Sarwono. 2012. Pengantar Psikologi Umum. Jakarta: Rajawali Pers

Utami, G.N.A. 2000. Efektivitas Teknik Bibliocounseling Untuk Meningkatkan Pengendalian Emosi Pada Siswa Kelas X MIPA Di SMA Negeri 7 Banjarmasin. Jurnal Pelayanan Bimbingan Dan Konseling. 3(2):164-172.

Wardhani, A.C. 2006. Faktor-Faktor yang Memengaruhi Perilaku Komunikasi Penyuluhan Pertanian. MediaTor. $\quad$ 7(2):269-280. https://doi.org/10.29313/mediator.v7i2.1293 